\title{
DEMAND PATTERNS FOR HIV-TESTS IN GENERAL PRACTICE: INFORMATION COLLECTED BY SENTINEL NETWORKS IN 5 EUROPEAN COUNTRIES
}

\author{
V. VAN CASTEREN*', P. LEURQUIN*, A. BARTELDS**, F. GURTNER ${ }^{* * *}$, \\ V. MASSARI $\dagger$, S. MAURICE-TISON $\dagger$, A.T. VEGA $\dagger \dagger \dagger$ and R. MAK* \\ *Institute of Hygiene and Epidemiology - J. Wytsmanstreet 14 - 1050 Brussels - Belgium. \\ ${ }^{* *}$ NIVEL - Utrecht - the Netherlands. \\ ***Federal Office of Public Health - Bern - Switzerland. \\ tINSERM - URBB - Paris - France. \\ f+University of Bordeaux II - Bordeaux - France. \\ H+Direccion General de Salud Publica Y Asistencia - Castilla y Leon - Spain.
}

Key words: HIV testing - Sentinel networks - General practice

This study describes a 1 year international data collection on the demand pattern for HIVantibody tests in general practice recorded by 6 sentinel networks in 5 European countries. The purpose of the recording was to evaluate the use of HIV-antibody testing by general practitioners and the demand for testing among the general population. Sentinel networks of general practitioners are a possible and available instrument for monitoring the perception of the HIV-test, and indirectly of the threat of the HIV-epidemic by the public and by the general practitioners (GPs). Differences were found between the countries in the frequency of testing, the person asking the test and the reason for testing. Possible explanatory factors, such as differences in the routine testing of specific groups, differences in the training and in the role of the GP, differences in the characteristics of prevention policy, are discussed. The European comparison also offers the opportunity to reflect on common medical practice in dealing with demands for HIV-tests.

\section{INTRODUCTION}

As the numbers of patients infected with human immunodeficiency virus (HIV) and with the acquired immune deficiency syndrome (AIDS) increase, general practitioners (GPs) will have an increasingly important role in screening for HIV antibody state, counselling patients positive for HIV and managing patients with AIDS. It can be considered that GPs are well placed to assess a patient's risk for getting HIVinfected (10).

\footnotetext{
$\overline{1}$ Corresponding author.
}

In the framework of the EC concerted action "Eurosentinel" (June 1988 - June 1991) - funded by the EC Medical Research Programme - Health Service Research - an international data collection on the demand pattern of HIV-antibody testing, recorded by six sentinel networks of GPs from 5 European countries, was carried out in $1990(16,17)$. The networks collected information on the age and sex of the patients being tested, the person initially requesting the test (GP or patient) and the reason for testing $(2,7,9,11,13,18)$.

The aims of this recording are to assess the extent to which HIV-antibody tests are prescribed in general 
practice, and to determine which patients are being tested and why. In this way, the sentinel networks can function as an indicator of the perception of risk for HIV infection and possible changes in this perception by the general population and by other groups (health professionals, insurance companies etc.). This recording also can reflect the need for and the possible impact of various interventions and information campaigns against AIDS. The recording might enable to detect at an early stage the additional needs of information in the general population or other groups regarding HIV-testing.

\section{MATERIALS AND METHODS}

The international data collection on the demand pattern for HIV-antibody testing in general practice, recorded in 6 sentinel networks from 5 European countries - Belgium, France ( 2 networks), Spain (since June 1990), Switzerland and Netherlands - ran from January 1990 to December 1990 (Table 1).

TABLE 1. - Participating networks in the recording of HIV-tests.

\begin{tabular}{ll}
\hline Name of the network & Country \\
\hline $\begin{array}{l}\text { Médecins vigies/Huisartsenpeil- } \\
\text { praktijken (N) }\end{array}$ & Belgium \\
$\begin{array}{l}\text { Réseau National Télématique de } \\
\text { Surveillance et d'Information sur les } \\
\text { Maladies Transmissibles (RNTMT) (N) }\end{array}$ & France \\
$\begin{array}{l}\text { Réseau Aquitaine Sentinelle (R) } \\
\text { Red de Medicos Centinelas de Castilla } \\
\text { y Leon (R) }\end{array}$ & France \\
$\begin{array}{l}\text { Sentinella (N) } \\
\text { Peilstations (N) }\end{array}$ & Spain \\
\hline $\mathrm{N}=$ national network. & Switzerland \\
$\mathrm{R}=$ regional network. & The Netherlands
\end{tabular}

In sentinel networks, data on defined health problems - infectious or non-infectious, acute or chronic - are gathered on a voluntary basis and anonymously, in general practices, processed by a central facility and reported to the participants and the public. With sentinel disease surveillance completeness is sacrificed to greater reliability, speed and often cost-effectiveness (5). Sentinel practices can be considered as a reliable source of information about different health problems in the population contacting the GP $(4,6)$.

Two of the sentinel networks involved in the HIV-antibody test recording are regional, the other are national networks (Table 1). The sentinel sites remain the same during the whole registration period.
In all the participating networks data collection is done by means of weekly forms, except for both French networks where the participating GPs are linked by electronic mail to a central computer. Practice lists for the estimation of the population denominator only are available in the Dutch and the Spanish network. In spite of the voluntary participation of the physicians in the networks, a considerable level of representativeness of the networks is aimed at. Several indicators of representativeness are regularly assessed and improved when necessary and possible, such as geographic distribution of the participants over the country or region (e.g. according to the degree of urbanisation, per province), age and sex distribution and number of years in practice compared with the GPs in the country or region. The recording does not include physicians with particular interest in HIVtesting and counselling and together with HIVantibody test, other health problems are also recorded by the networks.

Data were collected internationally by means of standard tables, sent by the Central Facility every three months to the coordinators of the networks. The standard tables contained the following variables: patient's age group and sex, person asking for the test (physician, patient, third party), reason for testing (Table 2), and test result. Information on the presence of risk factors is based on selfreported behaviour of the patient. Test results are only briefly discussed in this paper.

TÁBLE 2. - Standard table on reason for testing.

\author{
RISK FACTOR \\ homosexual/bisexual activity (only) \\ IV drug use \\ both of the above \\ haemophiliac \\ transfusion recipient \\ heterosexual activity: sexual contact with positive or at risk \\ heterosexual contact "at risk" \\ person origin in Pattern II country \\ STD patient \\ professional exposure \\ unknown
}

\section{REASON IN ABSENCE OF RISK FACTOR}

anxiety

symptoms suggestive for HIV infection

screening before/during pregnancy

screening before marriage

other ${ }^{3}$

\footnotetext{
${ }^{1}$ pattern II countries are defined by the WHO as those countries with a high rate of HIV infections and where the predominant means of transmission is heterosexual contact.

2 multiple heterosexual contacts, prostitutes, sexual partners not well known, violation, sexual contacts with prostitutes, etc...

3 visa, naturalization, life insurance, tattooage, pre-operation testing, etc...
} 
As different denominators are used in the participating networks, and in order to compare data internationally the frequency of HIV-testing was expressed as mean number of tests per GP, using the mean number of regularly participating GPs.

In the countries involved in this study cumulative AIDS incidence (31 December 1990) was highest in Switzerland $\left(242.9 / 10^{6}\right.$ inh.), followed by France $\left(234.1 / 10^{6}\right.$ inh.), Spain $\left(192.6 / 10^{6}\right.$ inh. $)$ the Netherlands (103.1/10 inh.) and Belgium $\left(82.9 / 10^{6}\right.$ inh.) (1). In the French Aquitaine region the cumulative AIDS incidence (31 December 1990) was $186.4 / 10^{6}$ inhabitants (14). In the Spanish Castilla y Leon region cumulative AIDS incidence (21 December 1990) was $58.9 / 10^{6}$ inhabitants (Centro Nacional de Epidemiologia, Madrid, Spain - personal communication).

\section{RESULTS}

\section{Frequency of testing}

The mean number of performed HIV-tests per GP and per year varied largely between the networks: from 17 tests/GP/year in the Swiss to 2 in Dutch and less than 1 in the Spanish network (Table 3).

\section{Age and sex distribution of the tested patients}

For all networks combined, $87 \%$ of the tested patients were aged 20 to 49 years. The female patients were younger than the male patients: $60 \%$ of the female patients were under age 30 years compared to $40 \%$ in the male patients. This age distribution pattern was comparable in nearly all the networks. In the Spanish network, nevertheless, $30 \%$ of the female patients and $20 \%$ of the male patients were under 15 years, whereas the under 15 years represented less than $2 \%$ in the other networks. The overall M/F sexratio was 1.1 , varying from 0.8 in the Dutch network to 1.7 in the Swiss network.

\section{Origin of the demand}

In both French networks and in the Spanish one most $(60 \%)$ of the prescribed tests were requested by the GP (Figure 1). In the Swiss and Dutch network respectively $58 \%$ and $87 \%$ were asked by the patient. In the Belgian network about $50 \%$ of the tests were asked by the GP. In the Swiss network, one fourth of the tests were asked by a third party - mainly by insurance companies - and $3 \%$ of the tests were executed following a request by the patient and the GP together.

TABLE 3. - Number of prescribed HIV-tests and number of HIV-tests per GP and per year.

\begin{tabular}{|c|c|c|c|c|c|}
\hline \multirow{2}{*}{$\begin{array}{l}\text { Country } \\
\text { Belgium }\end{array}$} & \multicolumn{2}{|c|}{$\mathrm{Nb}$ of tests performed } & \multirow{2}{*}{$\begin{array}{c}\begin{array}{c}\text { Mean weekly Nb } \\
\text { of particip. GP }\end{array} \\
112\end{array}$} & \multicolumn{2}{|c|}{$\begin{array}{l}\text { Mean Nb of } \\
\text { tests/GP/year }\end{array}$} \\
\hline & $1154^{*}$ & M: 559 & & 10.3 & $\mathrm{M}: \quad 5.0$ \\
\hline & & F : 593 & & & $F: 5.3$ \\
\hline \multirow[t]{2}{*}{ France/RNTMT } & 1094 & M: 511 & 104 & 10.5 & M: 4.9 \\
\hline & & F : 583 & & & $F: 5.6$ \\
\hline \multirow[t]{2}{*}{ France/Aquitaine } & 271 & M: 135 & $48^{* *}$ & 5.6 & $\mathrm{M}: \quad 2.8$ \\
\hline & & $F: 136$ & & & $\mathrm{~F}: 2.8$ \\
\hline \multirow[t]{2}{*}{ Spain } & $81^{*}$ & M: $\quad 47$ & 144 & $1 * * *$ & $\mathrm{M}: \quad 0.5$ \\
\hline & & $F: \quad 32$ & & & $\mathrm{~F}: 0.4$ \\
\hline \multirow[t]{2}{*}{ Switzerland } & $2345+$ & M: 1476 & 135 & 17.4 & M: 10.9 \\
\hline & & $F: 864$ & & & $F: 6.4$ \\
\hline \multirow[t]{2}{*}{ The Netherlands } & 120 & M: $\quad 52$ & 63 & 1.9 & $\mathrm{M}: \quad 0.8$ \\
\hline & & $F: \quad 68$ & & & $\mathrm{~F}: 1.1$ \\
\hline
\end{tabular}

* In 2 cases sex unknown

** Number of GPs having connected at least twice a month

*** Extrapolation up to 1 year

+ In 5 cases sex unknown. 


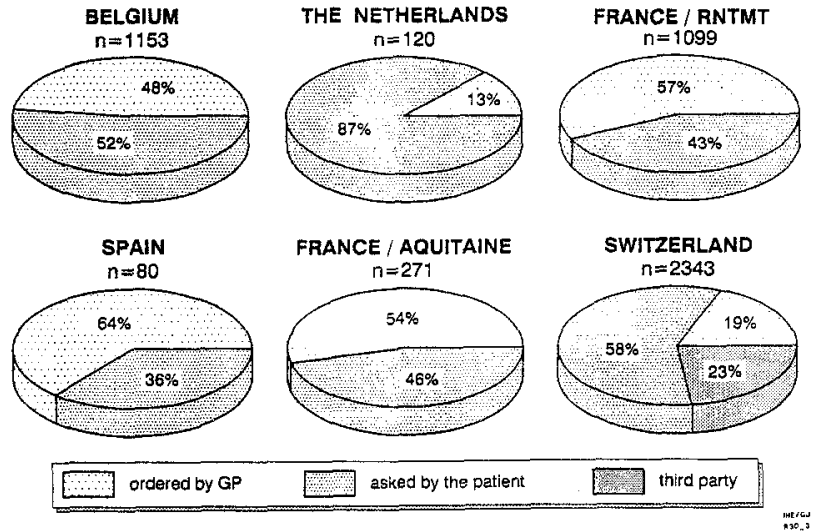

Figure 1. - Person asking for the HIV-test (\%).

\section{Main reason for testing}

Considering all tested patients, regardless who requested the test, most of the tested patients had a known risk factor in the Dutch $(83 \%)$ and Spanish $(69 \%)$ networks, mainly heterosexual contacts "at risk" and IV-drug use, respectively. In Belgium, France and Switzerland less than $50 \%$ of the tested patients had a known risk factor, mainly heterosexual contacts "at risk".

In the cases where men requested the test, heterosexual contacts "at risk" were the main reason in all networks, excepted the Spanish network, where it was IV drug use (Table 4).

A frequent or the most frequent reason why women wanted to be tested was heterosexual contacts "at risk" in all networks (Table 5). Another very frequently mentioned reason was anxiety without a

TABLE 4. - Main reason for testing male patients in the participating networks.

\begin{tabular}{|c|c|c|c|c|c|c|}
\hline Test ordered by GP & $\begin{array}{c}\text { Test/GP and } \\
\text { year }\end{array}$ & $\%$ & Country & $\%$ & $\begin{array}{c}\text { Tests/GP and } \\
\text { year }\end{array}$ & Tests asked by patient \\
\hline Other* & 0.5 & 35 & Belgium & 34 & 0.8 & Heterosex. contact "at risk" \\
\hline Heterosex. contact "at risk" & 0.4 & 29 & & 24 & 0.6 & Anxiety \\
\hline Total & 1.5 & & & & 2.4 & Total \\
\hline Screening before marriage & 1.4 & 48 & France RNTMT & 19 & 0.4 & Heterosex. cont. "at risk" \\
\hline STD patient & 0.4 & 13 & & 17 & 0.3 & Screening before marriage \\
\hline Total & 2.8 & & & & 2.1 & Total \\
\hline Screening before marriage & 0.6 & 41 & France/Aquitaine & 21 & 0.3 & Heterosex. cont. "at risk" \\
\hline Heterosex. contact "at risk" & 0.4 & 25 & & 20 & 0.3 & Anxiety \\
\hline Total & 1.4 & & & & 1.4 & Total \\
\hline Homos./Bisex. act. & 0.03 & 50 & The Netherlands & 63 & 0.5 & Heterosex. cont. "at risk" \\
\hline Symt. sugg, HIV-inf. & 0.03 & 50 & & 17 & 0.1 & Homos./Bisex. act \\
\hline Total & 0.06 & & & & 0.8 & Total \\
\hline IV-drug use & 0.14 & 39 & Spain** & 47 & 0.10 & IV drug use \\
\hline Other* & 0.05 & 18 & & 11 & 0.02 & Heterosex. cont. "at risk" \\
\hline Total & 0.35 & & & & 0.22 & Total \\
\hline Sympt. sugg. HIV-inf. & 0.5 & 26 & Switzerland & 34 & 1.9 & Heterosex. cont. "at risk" \\
\hline Heterosex. cont. "at risk" & 0.5 & 24 & & 28 & 1.5 & Anxiety \\
\hline Total & 2.0 & & & & 5.5 & Total \\
\hline
\end{tabular}

* Visa, naturalization, life insurance, tattooage, pre-operation testing etc.

** Extrapolation up to 1 year. 
TABLE 5. - Main reason for testing female patients in the participating networks.

\begin{tabular}{|c|c|c|c|c|c|c|}
\hline Test ordered by GP & Test/GP and & $\%$ & Country & $\%$ & Tests/GP and & Tests asked by patient \\
\hline Prenatal screening & 1.1 & 44 & Belgium & 36 & 0.6 & Anxiety \\
\hline Heterosex. contact "at risk" & 0.5 & 21 & & 36 & 0.6 & Heterosex. cont. "at risk" \\
\hline Total & 2.4 & & & & 1.7 & Total \\
\hline Prenatal screening & 1.3 & 42 & France RNTMT & 17 & 0.4 & Screening before marriage \\
\hline Screening before marriage & 1.1 & 33 & & 16 & 0.4 & Heterosex. cont. "at risk" \\
\hline Total & 3.2 & & & & 2.4 & Total \\
\hline Screening before marriage & 0.5 & 30 & France/Aquitaine & 27 & 0.3 & Anxiety \\
\hline Prenatal screening & 0.5 & 27 & & 20 & 0.2 & Heterosex. cont. "at risk" \\
\hline Total & 1.7 & & & & 1.1 & Total \\
\hline Prenatal screening & 0.17 & 92 & The Netherlands & 55 & 0.5 & Heterosex. cont. "at risk" \\
\hline Sympt. sugg. HIV-inf. & 0.02 & 8 & & 9 & 0.08 & $\begin{array}{l}\text { Heterosex. cont. with pos. } \\
\text { pers. }\end{array}$ \\
\hline Total & 0.2 & & & & 0.9 & Total \\
\hline Prenatal screening & 0.08 & 32 & Spain** & 50 & 0.05 & IV drug use \\
\hline IV drug use & 0.07 & 23 & & 20 & 0.02 & Heterosex. cont. "at risk" \\
\hline \multirow[t]{2}{*}{ Total } & 0.26 & & & 20 & 0.02 & Other* \\
\hline & & & & & 0.10 & Total \\
\hline Heterosex. cont. "at risk" & 0.3 & 26 & Switzerland & 31 & 1.3 & Heterosex. cont. "at risk" \\
\hline Sympt. sugg. HIV-inf. & 0.2 & 19 & & 30 & 1.3 & Anxiety \\
\hline Total & 1.2 & & & & 4.2 & Total \\
\hline
\end{tabular}

* Visa, naturalization, life insurance, tattooage, pre-operation testing etc.

** Extrapolation up to 1 year.

known risk factor in the Belgian, French Aquitaine and Swiss network.

In the cases where the GP ordered the test, the main reason for testing female patients was prenatal screening in the Belgian, the French RNTMT, the Spanish and the Dutch network (Table 5). In the France-Aquitaine network the most important reason was premarital screening and in the Swiss network it was heterosexual contacts "at risk".

Considering the cases where the GP ordered the test, the main reason for testing male patients was administrative reason in the Belgian network, premarital screening in the French networks, IV-drug use in the Spanish and symptoms suggestive for HIVinfection in the Swiss network (Table 4).

\section{Test result}

In the Spanish network results were not recorded. Of the 4984 tests performed in the other networks, 55 (1.1\%) were HIV-seropositive confirmed by Western blot or IF.

\section{DISCUSSION AND CONCLUSION}

This study describes an international data collection on the demand pattern for HIV-tests in general practice by 6 sentinel networks from 5 European countries. These sentinel networks are based on volunteers. Although several indicators of representativeness are regularly assessed in all the networks, their representativeness in the context of HIV-tests is difficult to assess. Therefore results should not be treated as representative of HIV screening practice in each country. In spite of this limitation, international comparison of the data between these networks seems valid, as the selection bias is present in all the networks involved. At the start of the international data collection, the recording was already running in five of the six networks, although not in a completely similar way. Standard tables were established for the international data collection. In view of the different denominators used in the networks, the frequency of HIV-testing was expressed as mean number of tests per GP and per year, using 
the mean number of regularly participating GPs. Nevertheless some differences persisted inherent in the specific organization of each network, such as the definition of regularity in participation. Despite these problems global comparisons of the demand pattern for HIV-antibody testing between the networks were possible and interesting differences could be revealed, especially concerning the frequency of testing, the person asking for the test, the presence of a risk behavior and the reason for testing.

This study reveals that testing of individuals without recognized high-risk behavior has become a common practice in several countries. In the networks where the number of HIV-tests per GP and per year was the highest, the proportion of tests for risk factors was the lowest.

The most or the second most important reason why patients wanted to be tested in all, but the Spanish network, was heterosexual contact "at risk". This can be an indicator of the public awareness of the potential heterosexual transmission of HIV. Also important to note is that in the Belgian, the FranceAquitaine and the Swiss network many patients wanted to be tested because of anxiety, without presenting a recognized risk behaviour.

"The information on the reason for the test is based on selfreported behaviour of the patient. To which extent risk behaviour such as homosexual contacts, extramarital sex or sex with prostitutes is reported by the patient when requesting a test, is probably very different from country to country. Selfreporting of homosexual contacts has also been found to depend on the quality of counselling (12), and the same can be assumed for other risk behaviour, which differs with moral values of the society, too. Finally, the judgement if a reported behaviour justifies the label 'risk behaviour' or can be dismissed as 'anxiety' depends on knowledge and attitudes of the individual GP. Results of surveys among GPs in at least two countries indicate that half or more of GPs felt inconfident in counselling patients in HIV - and AIDS - matters, due to both, lacking counselling skills and insufficient knowledge $(3,8)$.

The differences between the various countries in the demand pattern for HIV-antibody tests revealed in this study might indicate differences in the perception of the HIV-test, and indirectly of the threat of the HIV-epidemic by the public and by the GPs. These differences also can reflect, differences for instance, in the characteristics of the AIDS-epidemic between the various countries, differences in the characteristics of prevention policy, differences in the training and in the role of the GP, in the routinely testing of specific groups or differences in the presence of other possibilities to get tested. Two countries with a high test rate, namely Switzerland and France, also have a high prevalence of HIV-seropositives and a high cumulative incidence of AIDS-cases. The differences in the number of tests per GP between both French networks might be explained by the fact that the RNTMT-network includes the regions Ile-de-France and Provence-d'Azur where the HIV-epidemic is more important. In Switzerland, several private groups promoted even mandatory mass screening. Antenatal care and prenatal screening can be provided by GPs or by gynecologists in different proportions in the various countries. Differences in the routinely testing of specific groups in the various countries can help to explain the differences in reason for testing. In France some blood test (toxoplasmosis, syphilis, blood group) are compulsory before marriage and often an HIVtest, although not compulsory, is included in this package.

The very low number of HIV-tests performed by GPs in the Dutch network can among other things be explained by the presence of other structures being more accessible and more acceptable to the patient. Moreover, the HIV-problems are especially concentrated in the city of Amsterdam, while the 63 sentinel practices are homogeneously spread all over the country. Furthermore, Dutch GPs are not allowed to judge and investigate patients on their practice list in case of life-insurance arrangements.

In the Spanish network, the high proportion of IV drug users among the tested patients reflects the real high importance of this group at risk in Spain. This proportion might be higher than expected, due to the presence of 2 sentinel practices covering a high risk population, namely I.V. drug users of a rehabilitation center. A very high percentage of tested patients was under 15 years old, namely $30 \%$ of the female and $20 \%$ of the male patients, compared to less than $2 \%$ in the other networks. It is to note however that these data were based on only 7 months effective recording. According to their results for 1991 these percentages dropped to $14 \%$ and $6 \%$ respectively, which is still higher than in the other networks.

Children were mainly tested for administrative reasons, probably before entering school or kindergarten, when the parents were known as "persons at risk". On the other hand patients seemed to consult specialists rather than GPs for HIV-testing which can account for the low number of performed tests.

The very low number of HIV-tests performed by GPs in the Dutch and the Spanish network, as compared to the other networks, may also be explained by a difference in the organisation of health services: in these two countries patients are registered with a GP and can not request a test in another general practice, while patients in the other countries presented here are free to consult a GP of their choice.

This European comparison also offers the opportunity to reflect on common medical practice in dealing with demands for HIV-tests. For instance, is it justified that the GPs in Belgium and France order so many tests in the frame of prenatal screening and/or premarital screening?

A continuation of the international data collection over several years will be useful to detect possible changes in the demand pattern for HIV-tests which might indirectly indicate possible changes in 
the risk perception for AIDS in the various countries. This monitoring can generate recommendations to the health authorities of each participating country regarding the needs in information of the population, of health professionals and other groups (e.g., insurance companies). The European comparison also offers the opportunity to discuss if this recording should continue in the same way or should be completed or replaced by another indicator of perception of risk for HIV-infection by the population and by the GPs, such as extension of the topic from HIV-tests consultation to any consultation dealing with HIV and AIDS.

\section{Acknowledgements}

We thank the general practitioners, as well as the coordinators of the networks having participated in this study.

\section{REFERENCES}

1. Acquired immunodeficiency syndrome (AIDS) (1991): WHO European region - update to 31 December 1990 - Wkly Epidem. Rec. 66: 109-112.

2. Bartelds A.I.M. (1991): Continue morbiditeitstregistratie peilstations. Nederland 1988/ 1989 - NIVEL, Utrecht.

3. Boyd J.S., Kerr S., Mae R.D., Finnighan E.A. and Kilbane P.K. (1990): Knowledge of HIV infection and AIDS, and attitudes to testing and counselling among general practitioners in Northern Ireland Brit. J. Gen. Pract. 40: 158-160.

4. Evans A.S. (1982): Viral infections of humans. Epidemiology and control - Sec. ed. New York: Phenum Medical Book Co.

5. Eylenbosch W.J. and Noah N.D. (1988): Surveillance in Health and Disease - Oxford University Press, Oxford, New York, Tokyo.

6. Logan W.P.D. and Lambert P.M. (1976): Vital statistics. In: Hobson W., eds. The theory and practice of public health - Oxford: Oxford University Press pp. 9-31.
7. Massari V., Brunet J.B., Bouvet E. and Valleron A.J. (1988): Attitudes towards HIV-antibody testing among general practitioners and their patients - Eur. J. Epidemiol. 4: 435-438.

8. Meystre-Agostini G., Dubois-Arber F., Hausser D. and Zimmerman E. (1991): Médicins practiciens et prévention du SIDA - Schweizerische Aerztezeitung 72: 1255-1259.

9. Office fédéral de la sante publique (1990): Tests VIH en pratique général; une enquête Sentinella Bulletin de l'Office fédéral de la santé publique 43: 303-310.

10. Paauw D.S. and O'Neil D.F. (1990): Human immunodeficiency virus and the primary care phisician - J. Fam. Pract. 31: 646-650.

11. Red de Medicos Centinelas de Castilla y Leon (1991): Programma 1991, informe $n^{\circ} 7$ - Junta de Castilla y Leon, Consejeria de Sanidad y Bienestar Social.

12. Ross M.W. (1985): Psychosocial factors in admitting to homosexuality in sexual transmitted disease clinic - Sexually Transmitted Diseases 12: 83-86.

13. Salamon R., Dabis F. and Maurice S. (1988): HIV monitoring via general practice - Lancet ii: 395 .

14. Surveillance du SIDA en France (1991): Situation au 31 Décembre 1990 - BEH 7: 25-27.

15. Van Casteren V. (1981): Inventory of sentinel health information systems with GPs in the European Community. Situation up to March 1990 - Institut d'Hygiene et d'Epidémiologie, Bruxelles.

16. Van Casteren V., Bartelds A., Gurtner F., Massari V., Maurice-Tison S. and Vega A. (1991): Prescriptions of HIV-tests by sentinel networks of general practitioners in various European countries. Poster presentation at the seventh International Conference on AIDS - Florence, Italy, 16-21 June 1991.

17. Van Casteren V. and Leurquin P. (1991): Eurosentinel, concerted action on sentinel health information systems with GPs. Final report - Institut d'Hygiène et d'Epidemiologie, Bruxelles.

18. Van Casteren V. and Van Der Veken J. (1990): La morbidité en Belgique en 1988-1989 - Institut d'Hygiène et d'Epidémiologie, Bruxelles. 